Article

\title{
Reactant Feeding Strategy Analysis of Sodium Borohydride Hydrolysis Reaction Systems for Instantaneous Hydrogen Generation
}

\author{
Yih-Hang Chen * ${ }^{\mathbb{D}}$ and Jhih-Cyuan Lin \\ Department of Chemical and Materials Engineering, Tamkang University, New Taipei 25137, Taiwan; \\ xlease9550@hotmail.com \\ * Correspondence: yihhang@mail.tku.edu.tw
}

Received: 8 August 2020; Accepted: 7 September 2020; Published: 8 September 2020

\begin{abstract}
In this study, the operational procedure of an experiment and simulation for a hydrogen-on-demand system using sodium borohydride hydrolysis is proposed. For an isothermal operating condition of a packed-bed reactor, the dynamic response between the input $\mathrm{NaBH}_{4}$ feed $\left(F_{\mathrm{NaBH} 4,0(S)}\right)$ and the output hydrogen flowrate $\left(F_{H 2(S)}\right)$ of the reactor can be analytically derived and is a first-order transfer function. The time constant of this transfer function is a function of the reciprocal of the product of the reaction rate constant and the catalyst weight into the liquid volume of the reactor. The kinetic parameters of Co-B/IR-200 catalysts are regressed from the experimental $\mathrm{NaBH}_{4}$ hydrolysis reaction. The result shows a $30^{\circ} \mathrm{C}$ operating temperature increase (from $40^{\circ} \mathrm{C}$ till $70^{\circ} \mathrm{C}$ ) can shorten the dynamic response time of the hydrogen generation rate by around two-thirds. From theoretical derivation, a feeding strategy which supplies the combination of impulse function and step function of the $\mathrm{NaBH}_{4}$ feed flowrate can produce a hydrogen-on-demand system. However, for real applications, a combined pulse and step function of the $\mathrm{NaBH}_{4}$ feed flowrate is used due to limitations in pump capacity. Hence, a systematic feeding procedure can then be constructed to achieve the US Department of Energy's fuel cell start-up time target of less than $5 \mathrm{~s}$. to produce hydrogen. Finally, the experiment was set-up to validate the simulation result.
\end{abstract}

Keywords: sodium borohydride; hydrolysis reaction; hydrogen-on-demand; start-up; feeding strategy

\section{Introduction}

Hydrogen can be produced from a variety of sources and is highly efficient and non-carbon emitting while producing electricity when combined with a proton exchange membrane fuel cell. Sodium borohydride $\left(\mathrm{NaBH}_{4}\right)$ has high theoretical gravimetric hydrogen storage capacity of $10.8 \mathrm{wt} . \%$. The operating temperature of $\mathrm{NaBH}_{4}$ hydrolysis reaction is suitable for proton exchange membrane fuel cells. However, up to now, it has been difficult to meet vehicular application hydrogen storage capacity targets $[1,2]$. Consequently, most research attention has been redirected to the early market applications: Stationary power and $3 \mathrm{C}$ portable power [1,3-6]. In order to design cost effective hydrogen storage systems, non-noble metals, such as nickel, cobalt, $\mathrm{Co}-\mathrm{B}$, Ni-B, Ni-Co-B [7-14] were used as catalysts for $\mathrm{NaBH}_{4}$ hydrolysis reaction. The kinetics study on $\mathrm{NaBH}_{4}$ hydrolysis reaction with different kinds of non-noble catalysts have been classified into zero-order [7,9,11-15], first-order $[8,15,16]$ and Langmuir-Hinshelwood $[15,17,18]$. In this work, Co-B/IR-120 catalysts were chosen for cost reasons. Synthesis method and the characteristic of Co-B/IR-120 catalysts were proposed by Liu et al. [19]. The reaction kinetic study of the composition and the surface morphology of Co-B catalysts on the sodium borohydride hydrolysis reaction for hydrogen generation was investigated [20]. Co/B ratio and surface structure effected the frequency factor and activation energy of the reaction. Chen and 
Pan [20] found the optimal hydrogen performance and durability of $\mathrm{Co}-\mathrm{B} / \mathrm{resin}$ catalysts under synthetic conditions.

In the reactor design phase, Liu and Li [1] and Demirci et al. [2] have pointed out the design and operation problems of hydrogen generation systems. To solve these design problems, new reactor design concepts and operation methods are continuing to improve in order to overcome the vapour, heat management and hydrogen storage weight problems for portable $3 \mathrm{C}$ power generation devices $[4,5,17,21-26]$.

In real applications, some prototypes of hydrogen generator units using $\mathrm{NaBH}_{4}$ have been made: Industrial Taiwan Research Institute and Korean Fuel Cell Research Center have both designed $2 \mathrm{~W}$ prototypes for cellular phones [5,11]. Nanyang Technological University Fuel Cell Strategic Research Programme has developed $5 \mathrm{~W}$ prototypes using a Ru catalyst for micro PEM fuel cell applications [3]. Oak Ridge National Laboratory successfully developed and tested a $500 \mathrm{~W}$ prototype to meet different power requirements [27]. These prototypes demonstrated the feasibility of the $\mathrm{NaBH}_{4}$ hydrolysis reaction for hydrogen generation.

The target of US Department of Energy's fuel cell start-up time is less than $5 \mathrm{~s}$. This means the instantaneous hydrogen generation from sodium borohydride hydrolysis reaction systems must be achieved. In general, the dynamic response time of the hydrogen generation rate of sodium borohydride hydrolysis reaction systems depends on the performance of catalysts (reaction rate) and reactor design (operating temperature, bulk density of reactor). Normally, the dynamic response time of the hydrogen generation rate of sodium borohydride hydrolysis reaction systems is much longer than $5 \mathrm{~s}$. because of the time needs for proceeding the chemical reaction. This means it's difficult to achieve the start-up time target by the normal operating of the sodium borohydride hydrolysis reaction. Furthermore, few papers have discussed the start-up, re-start and shut down problems of sodium borohydride hydrolysis systems. These problems are important issues for commercialization.

The objective of this work is to propose an operational procedure to generate sufficient hydrogen in response to process demands. In Section 2, the experiment was set up, and the hydrogen generation from $\mathrm{NaBH}_{4}$ hydrolysis reaction was tested and recorded. In Section 3, the steady-state modeling of a packed-bed reactor (PBR) was built to simulate the hydrolysis reaction. The kinetic parameters of the Co-B/IR-200 catalyst were regressed from experimental data. In Section 4, the dynamic response of the hydrogen generation rate to feed $\mathrm{NaBH}_{4}$ flowrate was derived. Hydrogen-on-demand systems can be achieved by using a reactant feeding strategy, i.e., a combined impulse function and step function. In Section 5, the experiment was set-up to validate our simulation result.

\section{Experiment}

In this work, the hydrogen was generated from the $\mathrm{NaBH}_{4}$ solution hydrolysis reaction with Co-B/IR-120 catalysts. The material, catalysts, and experiment set-up were shown in the following sections.

\subsection{Materials}

Cobalt(II) chloride hexahydrate (purchased from Alfa Aesar, Haverhill, MA, USA, 98\% pure) was dissolved in deionized water to generate $\mathrm{Co}^{2+}$. Catalyst supports are Amberlite IR-120 resins (purchased from Sigma-Aldrich, St. Louis, MO, USA). The functions of sodium borohydride ( $98 \%$ pure, purchased from Sigma-Aldrich, St. Louis, MO, USA) are reduction agent and the reactant of $\mathrm{NaBH}_{4}$ hydrolysis reaction. The $\mathrm{pH}$ value of catalyst synthesis is manipulated by using sodium hydroxide (purchased from Shimakyu Co., Samut Sakhon, Thailand, 98\% pure). The water used in all our experiments was deionized.

\subsection{Catalyst Preparation}

The ion exchange and the chemical reduction methods [19] were used to prepare the Co-B catalyst. The detailed procedures are described below. 
In the first stage (the ion exchange method); $0.004 \mathrm{~kg}$ of IR-120 resin was washed in deionized water (for purification), drained, and subsequently mixed with $14.3 \times 10^{-6} \mathrm{~m}^{3}$ of $7.7 \mathrm{wt} . \% \mathrm{CoCl}_{2}$. The time and the rotational speed of the stir were set at $1 \mathrm{~h}$ and $100 \mathrm{rpm}$. The protons of the ion exchange resin (IR-120) were replaced by $\mathrm{Co}^{2+}$. At the end of the ion exchange, the excess and un-exchanged $\mathrm{Co}^{2+}$ were washed by the de-ionized water until the solution became colorless.

In the chemical reduction method; the ion exchange resin $\left(\mathrm{Co}^{2+} / \mathrm{IR}-120\right)$ was reduced to $\mathrm{Co}$ metal on the IR-120 surface by combining $50 \times 10^{-6} \mathrm{~m}^{3}$ of $10 \mathrm{wt} . \% \mathrm{NaBH}_{4}$ with the $\mathrm{Co}^{2+} / \mathrm{IR}-120$ in a container. The container was then placed in a heater and the thermostat set at $25^{\circ} \mathrm{C}$ and constantly stirred for $1 \mathrm{~h}$ at $350 \mathrm{rpm}$. Then, the Co-B/IR-120 catalyst was washed by de-ionized water until the solution became colorless. Finally, the water in the Co-B/IR-120 catalyst was removed in the vacuum drying oven at $80^{\circ} \mathrm{C}$ for 1 day.

\section{3. $\mathrm{NaBH}_{4}$ Hydrolysis Reaction Experiment Set-Up}

The experiment was set-up to investigate the hydrogen generation rate of the sodium borohydride hydrolysis reaction system. The flow diagram is shown in Figure 1.

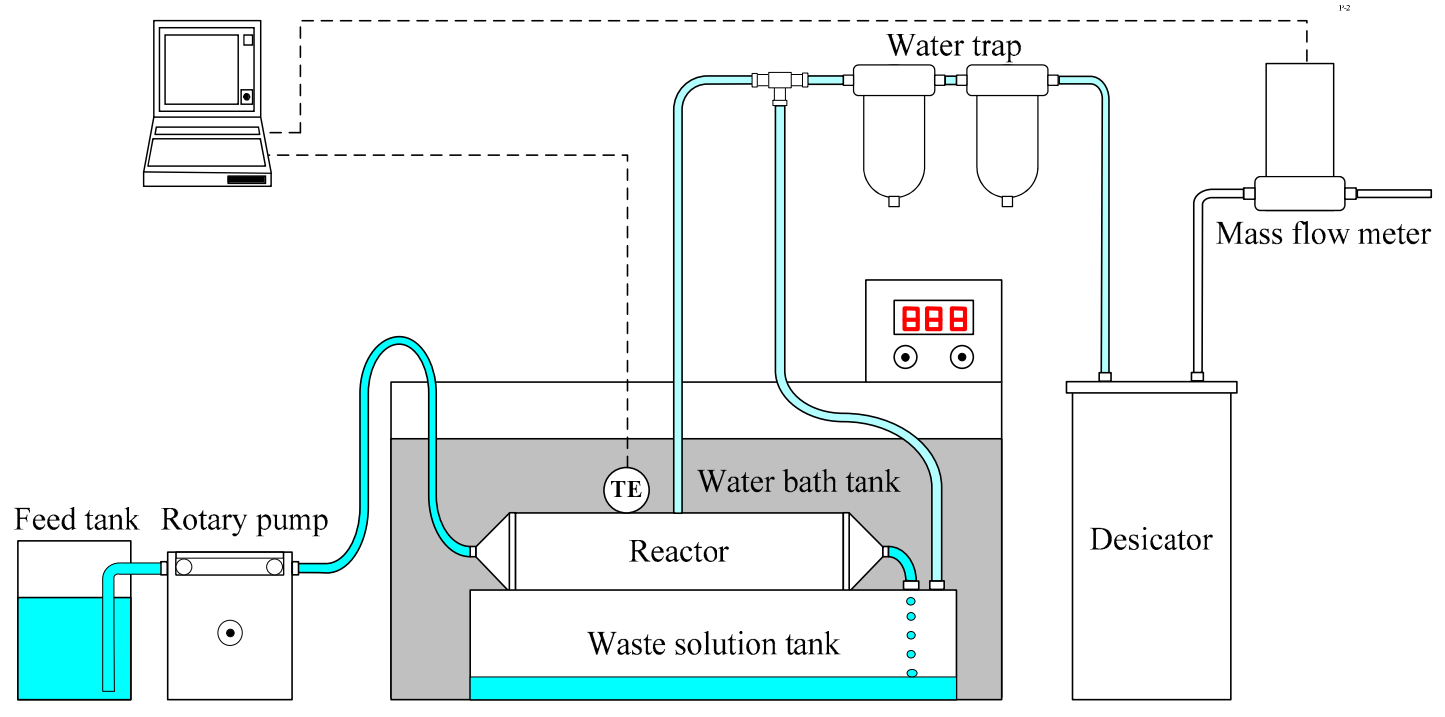

Figure 1. Experimental flow diagram of a sodium borohydride hydrolysis reaction for hydrogen generation.

The sodium borohydride solution was stored in a glass tank. The hydrolysis reaction experiment was carried out by pumping $5 \mathrm{wt} . \%$ of sodium borohydride and $2 \mathrm{wt} . \%$ of $\mathrm{NaOH}$ solution into a stainless reactor (cylindrical in shape with a diameter of $0.026 \mathrm{~m}$ and a length of $0.16 \mathrm{~m}$ ). In this reactor system, the reactor effluent stream exhibited a multiphase flow problem. This occurs when two phases exist in the reactor outlet stream: hydrogen, which is generated from $\mathrm{NaBH}_{4}$ hydrolysis reaction, and $\mathrm{NaBO}_{2}$ solution. As hydrogen volumetric flowrate is much larger than that of the liquid solution, hydrogen will force the unconverted $\mathrm{NaBH}_{4(\mathrm{aq})}$ solution out of PBR effluent tube. This reduces the $\mathrm{NaBH}_{4}$ conversion. In order to overcome this problem, a 'two exit channels' reactor was designed. Hydrogen was generated in the PBR and exited from the top channel. $\mathrm{NaBO}_{2(\mathrm{aq})}$ solution flowed out from the side channel. The configuration of the reactor is shown in Figure 2 and the PBR was placed in a horizontal manner. The sodium borohydride solution was fed into the reactor. Co-B/IR-120 catalyst particles were placed in the bottom of the reactor and fixed in place with a stainless grill. The PBR was immersed into a water bath in order to keep the reactor operating temperature at the desired level. Hydrolysis reaction took place and hydrogen was generated in the reactor. Outlet gases (hydrogen and steam) discharged from the top channel of the reactor and were measured by a mass flow meter (1179A, MKS, Andover, MA, USA). The data was transferred and recorded by a computer. 
Before entering the mass flow meter, the outlet gases were filtered by two water traps and then passed through a desiccator. In the hydrolysis reactor, a K-type thermocouple (GX-36, YOTEC Precision Instrument, Hsinchu, Taiwan) was connected to the reactor effluent stream to measure the reaction temperature and the data recorded on the computer.

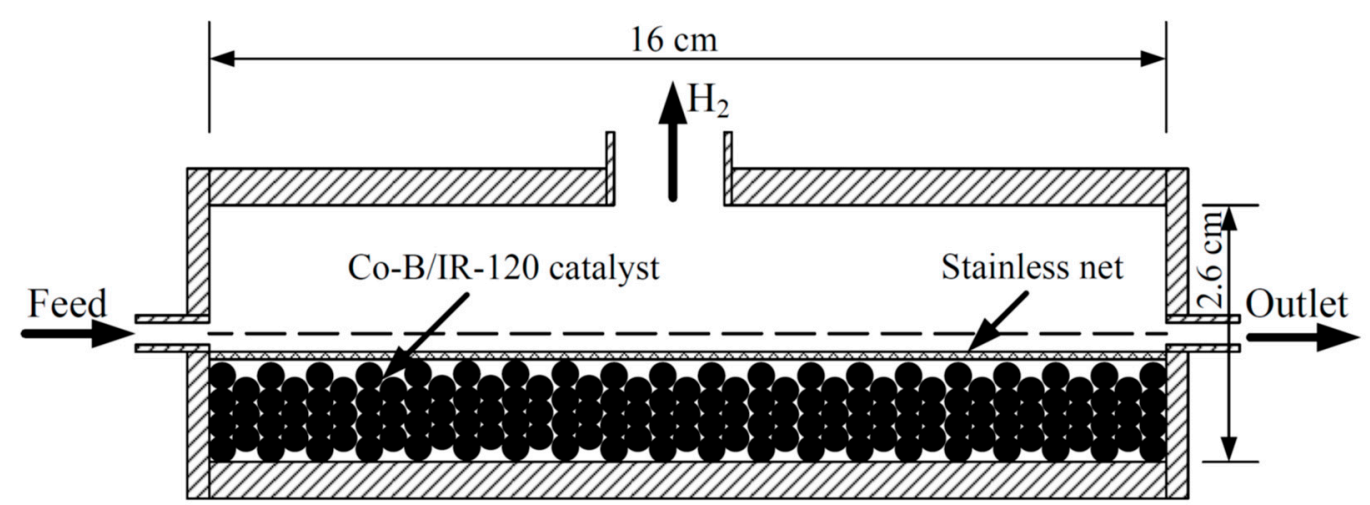

(a)

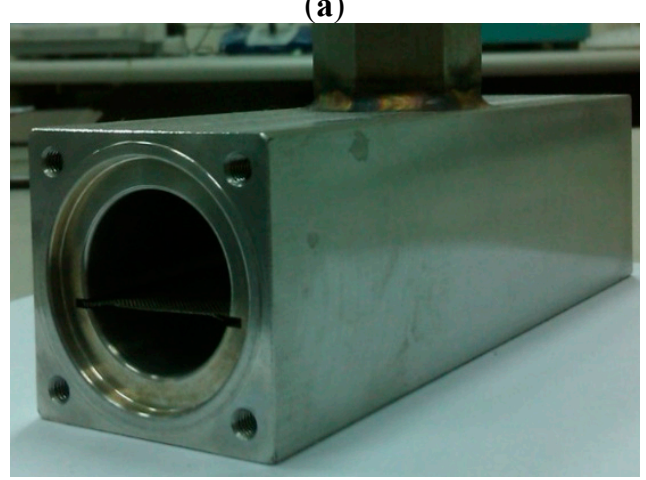

(b)

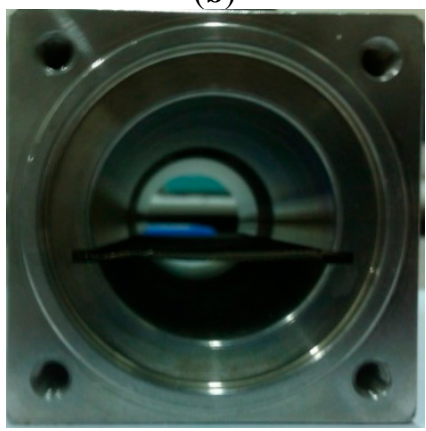

(c)

Figure 2. Reactor configuration for hydrogen generation using sodium borohydride hydrolysis reaction (a) mechanical diagram, photographs of experimental setup (b) 45 degree view, (c) side view.

\subsection{Experiment Data Treatment}

A typical rough data line of a hydrogen generation rate from $\mathrm{NaBH}_{4}$ hydrolysis reaction with Co-B/IR-120 catalysts was plotted versus time and is shown in Figure 3. The feed flowrate (which contained 5 wt.\% of $\mathrm{NaBH}_{4}$ and 2 wt.\% of $\mathrm{NaOH}$ water solution) and the catalyst weight were $1.02 \mathrm{~mL} \mathrm{~min}^{-1}$ and $0.0175 \mathrm{~kg}$, respectively. The operating temperature of the reactor was kept at $70{ }^{\circ} \mathrm{C}$ using a thermostat. The average hydrogen generation rate was around $130.02 \mathrm{~mL} \mathrm{~min}^{-1}$ (approximately 99.3\% conversion of $\mathrm{NaBH}_{4}$ ). Figure 3 shows the fluctuating original hydrogen generation flowrate raw data with respect to time. In order to eliminate the measurement noise, moving 
average method which was coded by MATLAB program was used to smooth out the experiment data as also shown in Figure 3 (solid line). The moving average line will be shown in future figures.

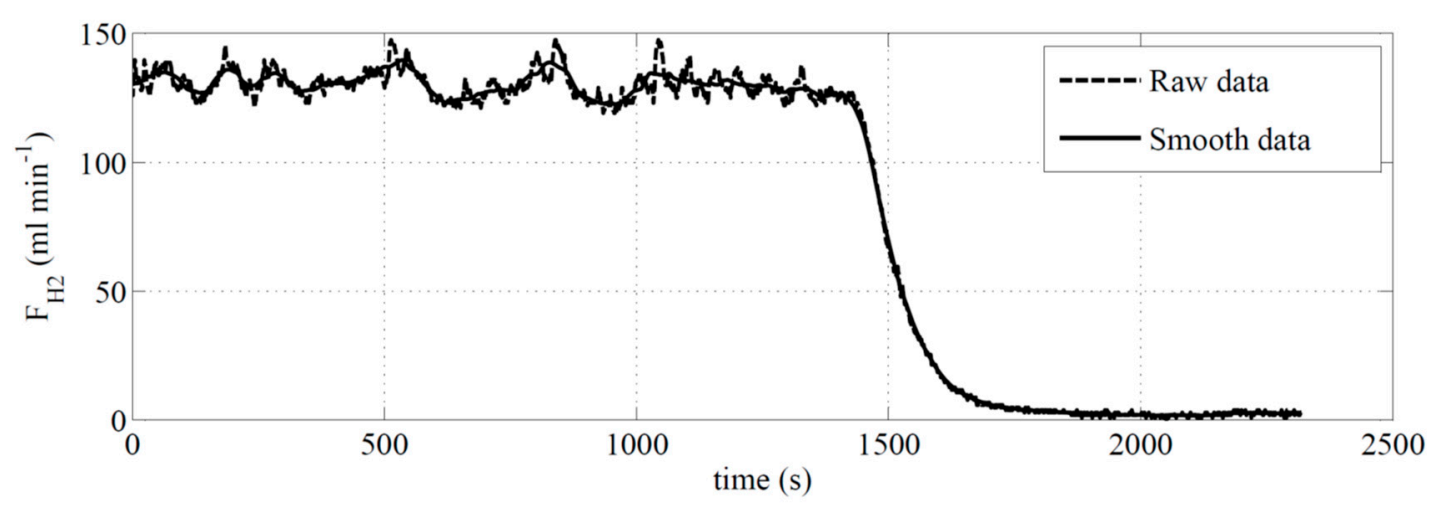

Figure 3. Reactor effluent hydrogen generation rate Raw experiment data (dash line) and smooth data (solid line).

\section{Process}

A schematic of a PBR for hydrogen generation from a $\mathrm{NaBH}_{4}$ hydrolysis reaction is shown in Figure 2. The reaction which took place in the reactor is shown as:

$$
\mathrm{NaBH}_{4}+2 \mathrm{H}_{2} \mathrm{O} \rightarrow \mathrm{NaBO}_{2}+4 \mathrm{H}_{2}
$$

\subsection{Process Modeling}

The mole balance and the stoichiometric relationship were used to construct a PBR model. The modeling assumptions are listed below. First, the lumps-model was used to describe the PBR. Second, the liquid volume of the PBR was fixed. Third, the energy balance equations were negligible in this system. This is because: (1) When the $\mathrm{NaBH}_{4}$ hydrolysis reaction takes place in the reactor, hydrogen bubbles which are generated on the catalyst surface cause disturbance in the solution resulting in uniform temperature throughout the solution. (2) In our experiment, the reactor size is relatively small. Therefore, there was no significant temperature change in radial direction in our measurements. Furthermore, the reactor was placed in a water bath to control the temperature.

The variation in the concentration of $\mathrm{NaBH}_{4}$ in the reactor with respect to time was the $\mathrm{NaBH}_{4}$ feed flowrate minus the $\mathrm{NaBH}_{4}$ outlet flowrate and the product of the rate of reaction and the catalyst weight of the reactor, which can be expressed as follows:

$$
V_{L, i} \frac{d\left(C_{\mathrm{NaBH} 4, i}\right)}{d t}=F_{\mathrm{NaBH} 4, i-1}-F_{\mathrm{NaBH} 4, i}-r_{\mathrm{NaBH} 4, i} W_{\mathrm{cat}, i}
$$

where $i$ denotes the $i$-th lump. $W_{\text {cat }, i}$ is the weight of catalyst $(\mathrm{kg})$ in $i$-th lump, $\mathrm{C}_{\mathrm{NaBH} 4, i}$ is the $\mathrm{NaBH}_{4}$ concentration (mol L ${ }^{-1}$ ) in $i$-th lump, $F_{\mathrm{NaBH} 4, i-1}$ and $F_{\mathrm{NaBH} 4, i}$ are the $\mathrm{NaBH}_{4}$ feed inlet and outlet flowrate ( $\mathrm{mol} \mathrm{min}^{-1}$ ) in $i$-th lump. $r_{\mathrm{NaBH}, i}$ is the $\mathrm{NaBH}_{4}$ reaction rate $\left(\mathrm{mol} \mathrm{g}_{\text {-cat }}{ }^{-1} \mathrm{~min}^{-1}\right)$ in $i$-th lump. $V_{L, i}$ is the liquid phase volume of the reactor (L) in $i$-th lump.

The variation in concentration of $\mathrm{H}_{2} \mathrm{O}$ with respect to time is shown as:

$$
V_{L, i} \frac{d\left(C_{H 2 O}, i\right)}{d t}=F_{H 2 O, i-1}-F_{H 2 O, i}-2 r_{N a B H 4, i} W_{c a t, i}-n_{e v a p, i} W_{c a t, i}
$$

where $C_{H 2 O, i}$ is the $\mathrm{H}_{2} \mathrm{O}$ concentration ( $\mathrm{mol} \mathrm{L}^{-1}$ ) in $i$-th lump, $F_{H 2 \mathrm{O}, i-1}$ and $F_{H 2 O, i}$ are the $\mathrm{H}_{2} \mathrm{O}$ feed inlet and outlet flowrate $\left(\mathrm{mol} \mathrm{L}^{-1}\right)$ in $i$-th lump, respectively. $n_{\text {evap }, i}$ is water vapor flowrate $\left(\mathrm{mol} \mathrm{g}_{\text {-cat }}{ }^{-1} \mathrm{~min}^{-1}\right)$ 
in $i$-th lump [28]. The variation in concentration of sodium metaborate $\left(\mathrm{NaBO}_{2}\right)$ with respect to time is shown as:

$$
V_{L, i} \frac{d\left(C_{\mathrm{NaBO} 2, i}\right)}{d t}=r_{\mathrm{NaBH} 4, i} W_{\mathrm{cat}, i}
$$

where $\mathrm{C}_{\mathrm{NaBO} 2, i}$ is the $\mathrm{NaBO}_{2}$ concentration $\left(\mathrm{mol} \mathrm{L}{ }^{-1}\right)$.

The hydrogen generation rate can be computed and the equation is shown as follows:

$$
F_{H 2, i}=4 \cdot r_{\mathrm{NaBH} 4, i} W_{c a t, i}
$$

where $F_{H 2, i}$ is the hydrogen generation rate $\left(\mathrm{mol} \mathrm{min}^{-1}\right)$ in $i$-th lump.

Equations (2)-(5) can be solved by using the Euler's explicit method; the code was programmed in Matlab.

\subsection{Steady-State Kinetic Parameters Regression}

The first-order kinetics for the hydrolysis reaction was used and can be expressed as follows:

$$
r_{\mathrm{NaBH} 4, i}=k \cdot \mathrm{C}_{\mathrm{NaBH}, i}
$$

where $k$ is the reaction rate constant $\left(\mathrm{L} \mathrm{g-cat}{ }^{-1} \mathrm{~min}^{-1}\right)$.

$$
F_{\mathrm{NaBH} 4, i}=\mathbf{v}_{0} \mathrm{C}_{\mathrm{NaBH}, i}
$$

where $v_{0}$ is the volumetric feed flowrate $\left(\mathrm{L} \mathrm{min}^{-1}\right)$.

Substituting Equations (6) and (7) into Equation (2) for steady-state operation, it gives:

$$
v_{0} C_{\mathrm{NaBH} 4, i-1}-v_{0} \mathrm{C}_{\mathrm{NaBH} 4, i}-k \mathrm{C}_{\mathrm{NaBH}, i} W_{\mathrm{cat}, i}=0
$$

Rearranging Equation (8), the concentration of $\mathrm{NaBH}_{4}$ can be obtained as follows:

$$
C_{\mathrm{NaBH}, i}=\frac{v_{0} \mathrm{C}_{\mathrm{NaBH} 4, i-1}}{v_{0}+k W_{c a t, i}}
$$

where $i$ is reactor lump number and reactor lumped numbers set at 175 in our simulation in order to make the simulation result more accuracy.

Table 1 shows the experimental hydrogen generation rates vs. reactor operating temperatures. The operating conditions of Table 1 were based on a catalyst weight of $0.0175 \mathrm{~kg}$ in the reactor, with a $1.02 \mathrm{~mL} \mathrm{~min}^{-1}$ feed flow rate of $5 \mathrm{wt} . \% \mathrm{NaBH}_{4}$ with $2 \mathrm{wt}$ \% $\mathrm{NaOH}$ solution. When the reactor operating temperatures changed from 30 to $70{ }^{\circ} \mathrm{C}$, the hydrogen generation rate increased from 83.45 to $130.02 \mathrm{~mL} \mathrm{~min}^{-1}$. In order to determine the reaction kinetic parameters for Co-B/IR-120 catalysts, the PBR modeling equations were used to find out the reaction rate constants for different operating temperatures.

Table 1. The experimental hydrogen generation rates vs. reactor operating temperatures.

\begin{tabular}{ccc}
\hline $\boldsymbol{T}$ & $\boldsymbol{F}_{\boldsymbol{H} \mathbf{2}}$ & $\boldsymbol{k}$ \\
\hline${ }^{\circ} \mathbf{C}$ & ${\mathbf{~ m L ~} \text { in }^{-\mathbf{1}}}$ & $\mathbf{L ~ c a t - g}^{\mathbf{1}} \mathbf{~ m i n}^{\mathbf{- 1}}$ \\
\hline 30 & 83.45 & $5.9142 \times 10^{-5}$ \\
40 & 106.49 & $9.7924 \times 10^{-5}$ \\
50 & 116.47 & $1.2853 \times 10^{-4}$ \\
60 & 125.66 & $1.8693 \times 10^{-4}$ \\
70 & 130.02 & $2.8225 \times 10^{-4}$ \\
\hline
\end{tabular}


For a given operating temperature, the volumetric feed flowrate $\left(v_{0}\right)$, the feed concentration of $\mathrm{NaBH}_{4}\left(C_{\mathrm{NaBH} 4, i-1}\right)$, and the catalyst weight $\left(W_{c a t, i}\right)$ in $i$-th lump reactor, and approximate reaction rate constant $(k)$ can determine the concentration of $\mathrm{NaBH}_{4}\left(\mathrm{C}_{\mathrm{NaBH} 4, i}\right)$ in $i$-th lump reactor as shown in Equation (9). $C_{\mathrm{NaBH} 4, i}$ in each lump of the reactor can be calculated sequentially. The hydrogen and concentration profiles along the reactor length can be calculated by using Equations (5), (6) and (9). The reaction rate constant $(k)$ was adjusted in order to fit the experimental hydrogen generation rate at the reactor effluent stream. The simulation and experiment data regression results (The circle symbols denote the hydrogen generation rates at different operating temperatures) are shown in Figure 4. The regressed reaction rate constants for different reactor operating temperatures are shown in Table 1 . The conversions at $30{ }^{\circ} \mathrm{C}, 40{ }^{\circ} \mathrm{C}, 50{ }^{\circ} \mathrm{C}, 60^{\circ} \mathrm{C}$ and $70{ }^{\circ} \mathrm{C}$ are $63.7 \%, 81.3 \%, 88.9 \%, 95.9 \%$ and $99.3 \%$, respectively.

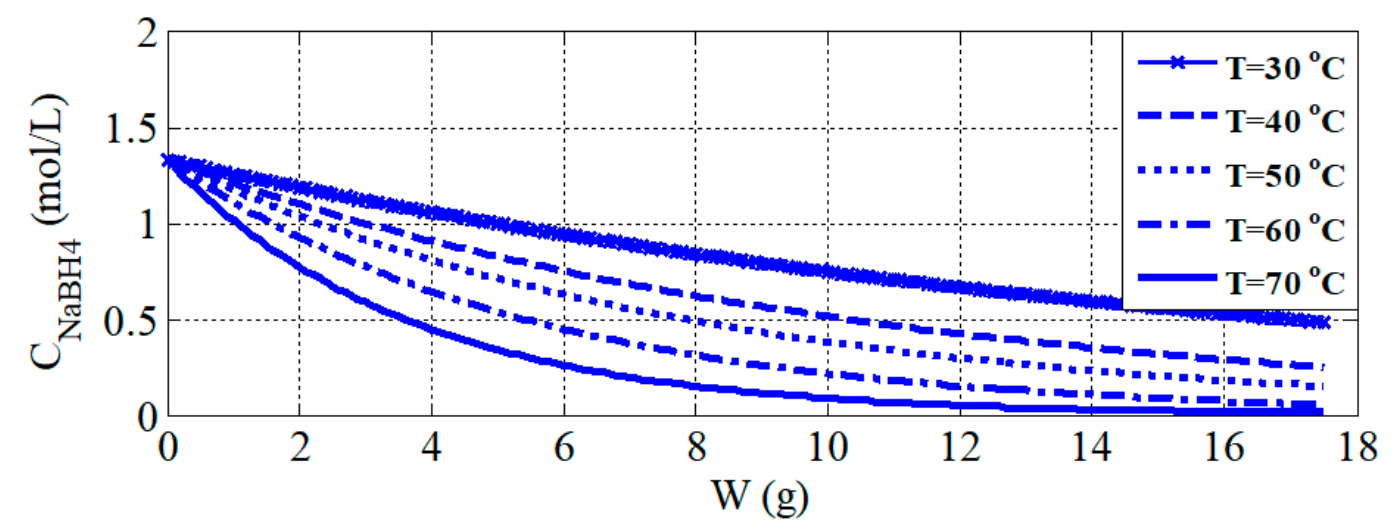

(a)

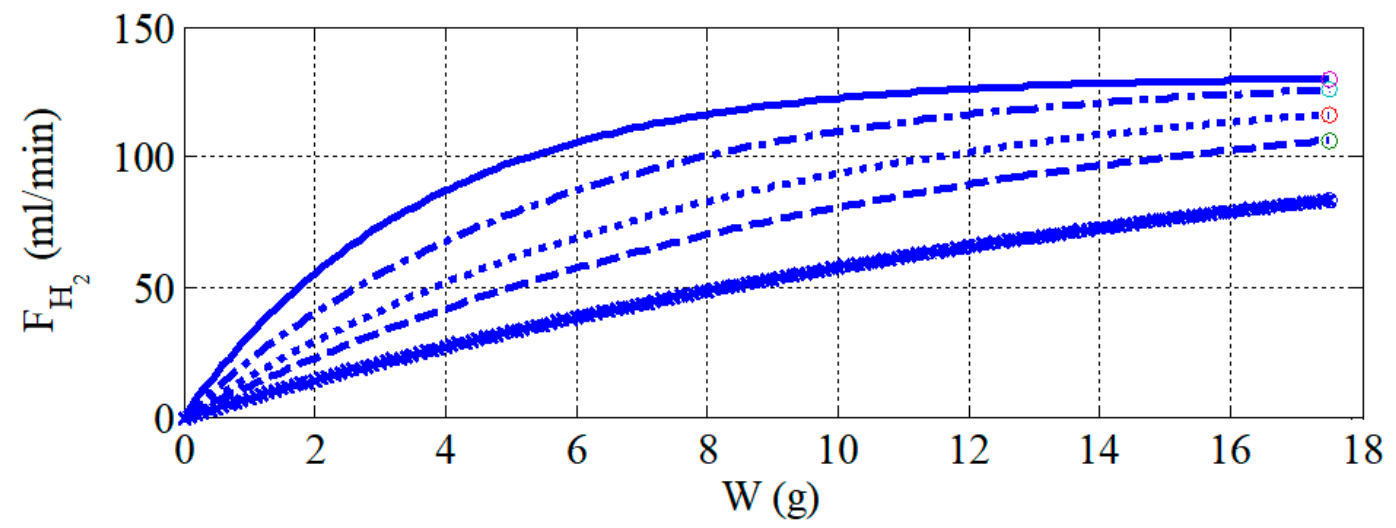

(b)

Figure 4. Steady-state simulation of (a) the concentration, (b) and the accumulated hydrogen generation rate profile along the reactor length at different operating temperatures. The circle data denotes the hydrogen generation rates at different operating temperatures.

In addition, the reaction rate constant can be expressed as an Arrhenius equation:

$$
k=k_{0} \exp \left(\frac{-E}{R T}\right)
$$

where $k_{0}$ is the frequency factor $\left(\mathrm{L} \mathrm{g-cat}{ }^{-1} \mathrm{~min}^{-1}\right)$. and $E$ is the activation energy $\left(\mathrm{kJ} \mathrm{mol}^{-1}\right)$. $R$ is the gas constant $\left(\mathrm{kJ} \mathrm{mol}^{-1} \mathrm{~K}^{-1}\right)$. After taking the natural logarithm of both sides of Equation (10), we have:

$$
\ln k=\ln k_{0}-\frac{E}{R T}
$$


Table 1 shows a set of temperatures and reaction rate constant data. Figure 5 shows the linear least-squares regression results. The circles and the solid line are the experiment data and regression results. The linear least-squares regression method can be used for finding $k_{0}$ and $E$ from the intercept and the slope of Equation (11). In our simulation, the first order reaction kinetic and PBR was used. The $k_{0}$ and $E$ are $25.27 \mathrm{~L} \mathrm{g-cat}{ }^{-1} \mathrm{~min}^{-1}$ and $32.62 \mathrm{~kJ} \mathrm{~mol}^{-1}$, respectively. The value of $R^{2}$ is 0.9932. However, almost all Co based catalysts use zero-order reaction kinetic, activation energy is $66.67 \mathrm{~kJ} \mathrm{~mol}^{-1}$ [19], $57.9 \mathrm{~kJ} \mathrm{~mol}^{-1}$ [9], $64.97 \mathrm{~kJ} \mathrm{~mol}^{-1}$ [11] and $44.47 / 54.89 \mathrm{~kJ} \mathrm{~mol}^{-1}$ [29]. However in this study, the kinetic behavior of Co-B/IR-120 catalyst is not zero-order reaction. Using first order reaction kinetic fit with our experimental data well.

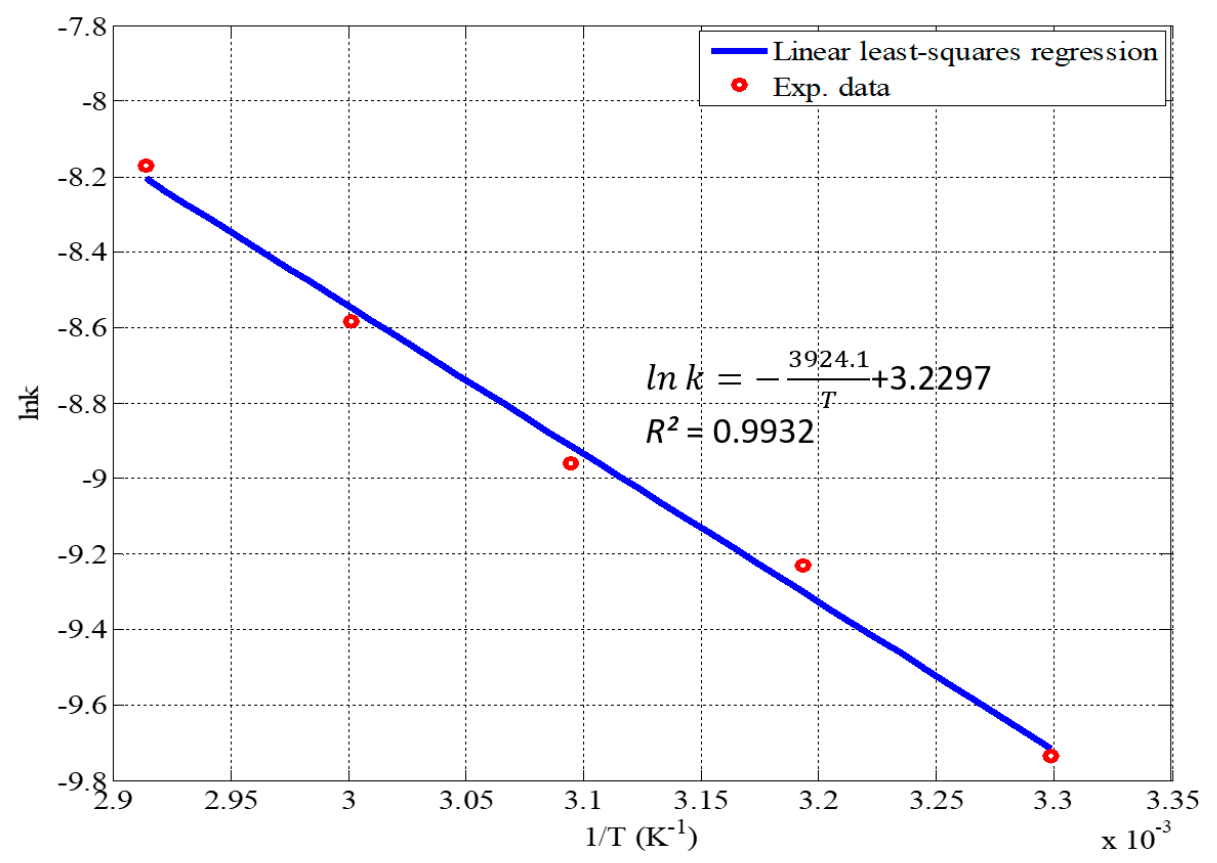

Figure 5. Linear least-squares regression for calculating kinetic parameters.

\section{Dynamic Characteristic Analysis of the PBR}

When the feed inlet flowrate is shut down from 1.02 to $0 \mathrm{~mL} \mathrm{~min}^{-1}$, the dynamic response of the hydrogen generation rate of the sodium borohydride hydrolysis reactor is shown in Figure 3. The settling time [30], which is around $392 \mathrm{~s}$. at $70{ }^{\circ} \mathrm{C}$, is defined as "the time it takes the amplitudes of oscillations to decay to some fraction of the change in set-point". The fraction of the change in set-point is $\pm 2 \%$ in this study. In order to achieve the on-demand hydrogen generation rate, the dynamic response of hydrogen generation rate of the PBR should be increased (shortening the settling time). Thus, the key factors affecting the dynamic characteristic of the hydrogen generation rate will be identified in this section.

\subsection{Dynamic Hydrogen Generation Data Fitting of the PBR}

The dynamic response of the PBR reactor hydrogen generation rate can be solved by using Equations (2)-(7). Figure 6 shows the dynamic response of the hydrogen generation rate with respect to time for our experiment data and simulation results with a step change of inlet flowrate. The feed condition was the same as in Section 2.4. The PBR was placed in a heating vessel to keep the operating temperature at $40^{\circ} \mathrm{C}$ or $70^{\circ} \mathrm{C}$. The liquid volume of the reactor (not including catalyst water content), $V_{L}$, was $8 \times 10^{-6} \mathrm{~m}^{3}$. The hydrogen generation rate of the PBR reached steady-state conditions within $1200 \mathrm{~s}$. At that stage the feed flowrates were shut down from 1.02 to $0 \mathrm{~mL} \mathrm{~min}{ }^{-1}$. The experiment results are shown in Figure 6 (solid line) for different operating temperatures. The hydrogen generation rate at $40{ }^{\circ} \mathrm{C}$ was around $106.5 \mathrm{~mL} \mathrm{~min}^{-1}$ and continued generating for around $1166 \mathrm{~s}$ and reduced 
to $\pm 2 \%$ of the final value (shown in Figure 6a). The hydrogen generation rate at $70{ }^{\circ} \mathrm{C}$ was around $130.02 \mathrm{~mL} \mathrm{~min}^{-1}$ and continued generating for around $392 \mathrm{~s}$. and reduced to $\pm 2 \%$ of the final value (shown in Figure 6b). The settling time of hydrogen generation rate at $40^{\circ} \mathrm{C}$ is almost three times longer than at $70{ }^{\circ} \mathrm{C}$. There are two reasons for this difference: The un-reacted $\mathrm{NaBH}_{4}$ in the $\mathrm{PBR}$ at $70{ }^{\circ} \mathrm{C}$ is less than at $40^{\circ} \mathrm{C}$. This statement can be proven and results are shown in Figure 4a. The second reason is the reaction rate at $70^{\circ} \mathrm{C}$ is faster than at $40^{\circ} \mathrm{C}$. Using Euler's method to solve the Equations (2)-(7), the dynamics simulation results are shown in Figure 6 (dashed line) and fit with the experiment data very-well without changing any parameters.

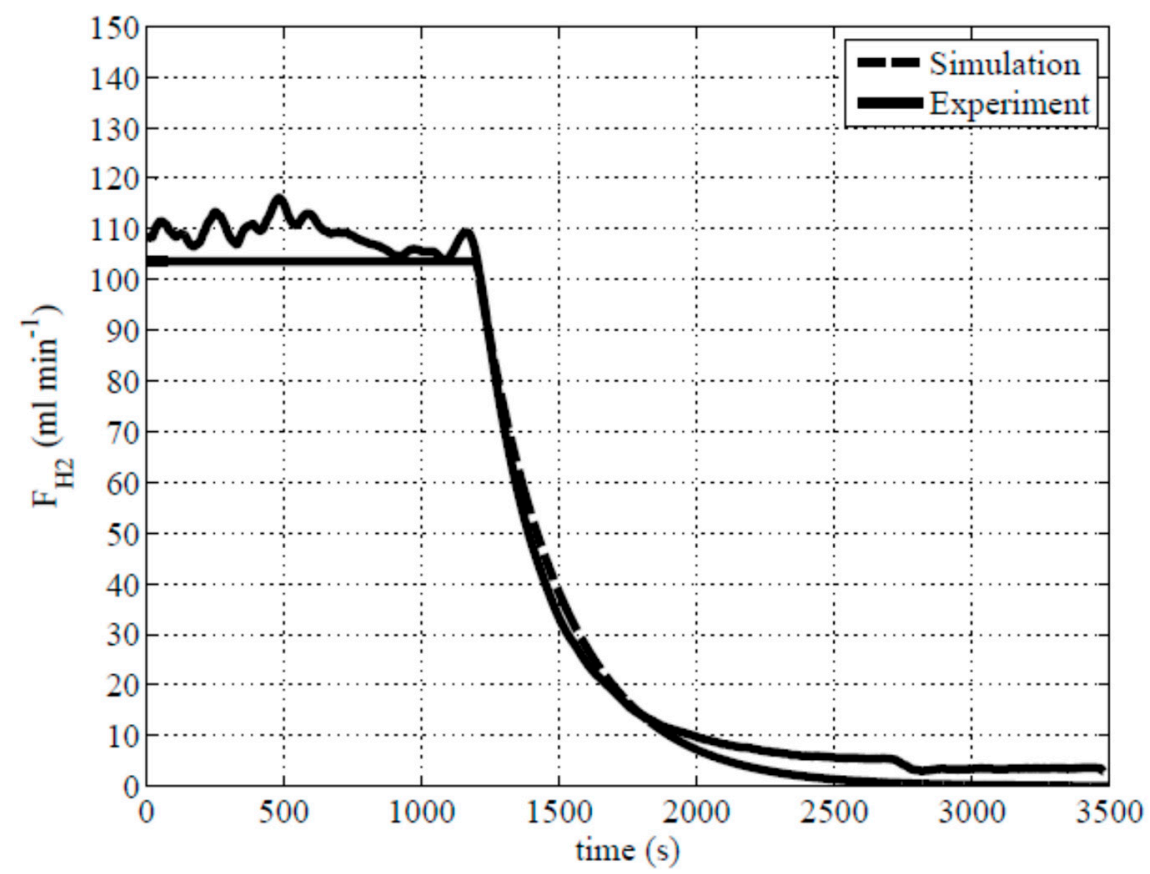

(a)

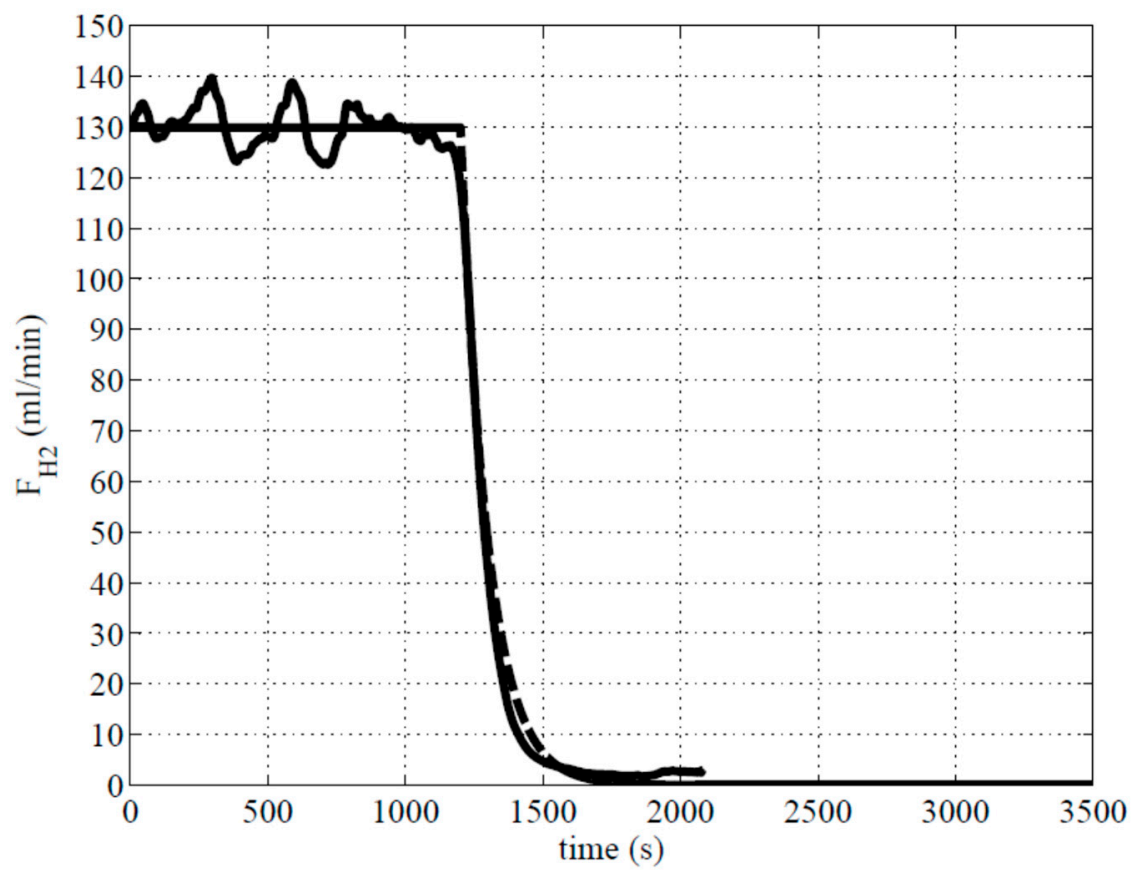

(b)

Figure 6. Dynamic response of the hydrogen flowrate at (a) $40{ }^{\circ} \mathrm{C},(\mathbf{b}) 70{ }^{\circ} \mathrm{C}$. 


\subsection{Dynamic Characteristic of the Hydrogen Generation Rate in the PBR}

The last section shows a step change in the reactor inlet flowrate generated a slow decrease in dynamic response of the reactor outlet hydrogen generation flowrate. In order to attain the instantaneous hydrogen generation profile, the relationship between dynamic response of the hydrogen generation flowrate and the feed $\mathrm{NaBH}_{4}$ flowrate needs to be derived and shown below.

Substituting Equation (6) into Equation (2), it gives:

$$
V_{L, i} \frac{d\left(C_{\mathrm{NaBH} 4, i}\right)}{d t}=F_{\mathrm{NaBH} 4, i-1}-F_{\mathrm{NaBH} 4, i}-k C_{\mathrm{NaBH} 4, i} \mathrm{~W}_{\mathrm{cat}, i}
$$

Also, substituting Equation (6) into Equation (5), we obtain:

$$
F_{H 2, i}=4 \cdot k \cdot C_{\mathrm{NaBH} 4, i} \cdot W_{c a t, i}
$$

Rearranging Equation (13), the concentration of $\mathrm{NaBH}_{4}$ can be obtained as:

$$
C_{\mathrm{NaBH} 4, i}=\frac{F_{H 2, i}}{4 k W_{c a t, i}}
$$

Substituting $\mathrm{C}_{\mathrm{NaBH} 4, i}$ using Equation (14) into Equation (12) gives:

$$
V_{L, i} \frac{d\left(F_{H 2, i} / 4 k W_{c a t, i}\right)}{d t}=F_{N a B H 4, i-1}-F_{N a B H 4, i}-\frac{F_{H 2, i}}{4}
$$

Because of the constant reaction temperature, the reaction rate constant $(k)$ was kept at the same value. And Equation (16) can be obtained as follows:

$$
\frac{V_{L, i}}{4 k W_{c a t, i}} \frac{d\left(F_{H 2, i}\right)}{d t}=F_{\mathrm{NaBH} 4, i-1}-F_{\mathrm{NaBH} 4, i}-\frac{F_{H 2, i}}{4}
$$

The PBR was modeled by lumping 175 CSTRs in series. Taking deviation variables and Laplace Transform of Equation (16), the transfer function between the input $\mathrm{NaBH}_{4}$ molar flowrate $\left(F_{\mathrm{NaBH} 4,0}\right)$ and the output hydrogen generation molar flowrate $\left(F_{H_{2}}\right)$ can be derived analytically (the derivation details from Equation (16) to Equation (17) are shown in the Appendix A):

$$
F_{H 2}(s)=\frac{4}{\frac{V_{L}}{k W_{c a t}} s+1} F_{\mathrm{NaBH} 4,0}(s)=\frac{K}{\tau s+1} F_{\mathrm{NaBH} 4,0}(s)
$$

where $\tau=\frac{V_{L}}{k W_{\text {cat }}}$ and $K=4$.

$\tau$ is the process time constant ( $\mathrm{min}$ ), which is the reciprocal of the product of the reaction rate constant and the catalyst weight into the liquid volume of the reactor. $K$ is the process gain, which follows the reaction stoichiometry of 4.0. The time constant $(\tau)$ of Equation (17) can be calculated and the value is $1.67 \mathrm{~min}\left(=0.008 / 2.7310 \times 10^{-4} / 17.5\right)$ (or $\left.100.4 \mathrm{~s}\right)$ at $70^{\circ} \mathrm{C}$. The simulation result of Equation (17) is shown in Figure 7. When a step changes in $F_{\mathrm{NaBH} 4,0}$, the settling time of the open loop dynamic simulation of the hydrogen generation rate $\left(F_{H 2}\right)$ is around $392 \mathrm{~s}$.

With a simple first-order transfer function available, the responses of the process to the step input of the sodium borohydride flow rate can be explored. The faster step response of the hydrogen generation rate can be obtained by operating at higher temperature or choosing high performance catalysts (higher value of rate constant $(k)$ ) in order to attain instantaneous hydrogen generation rate. The results are shown in Figure 6. However, it's inefficient to achieve instantaneous hydrogen generation rate by adjusting operating temperature or high performance catalysts. 

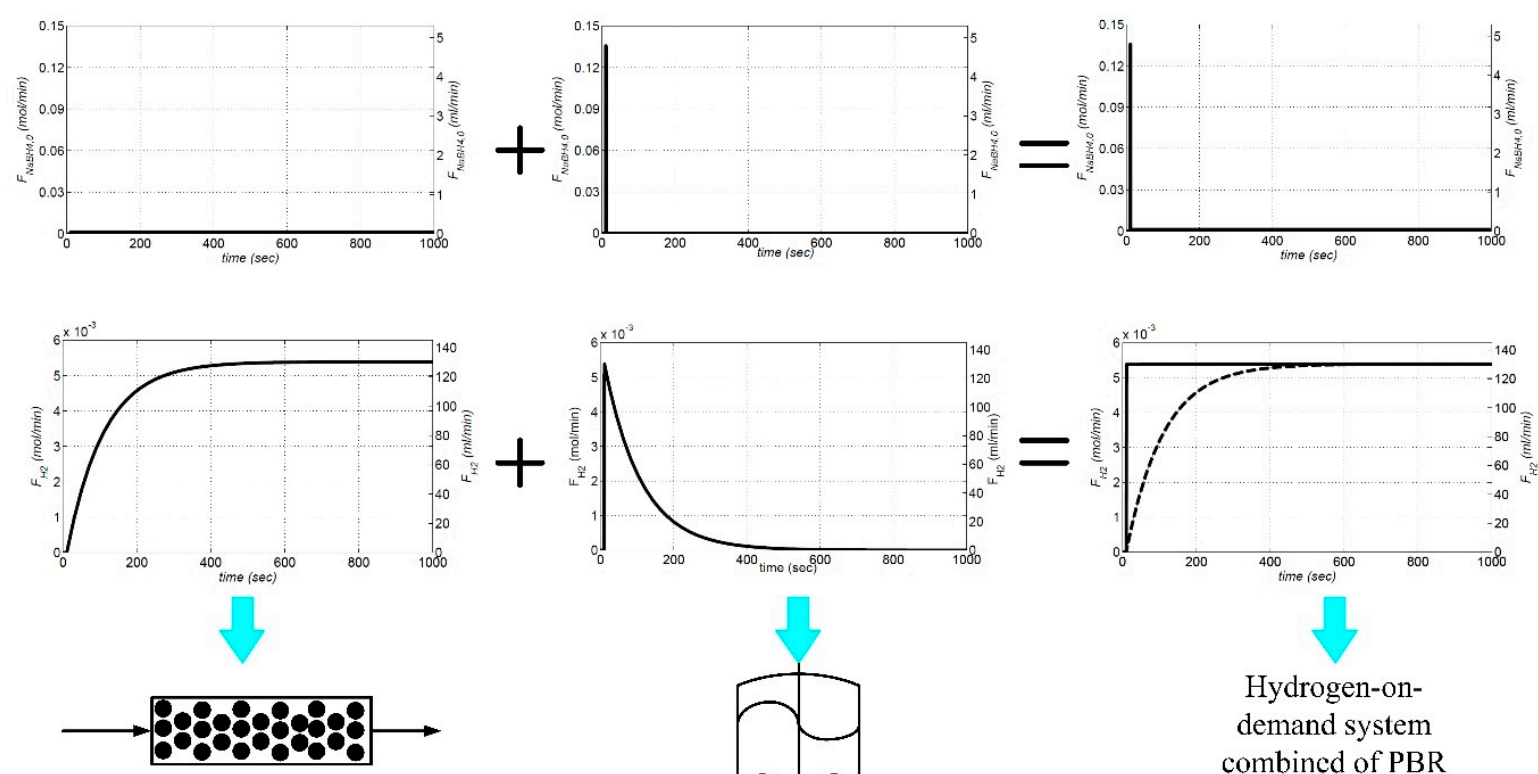

PBR

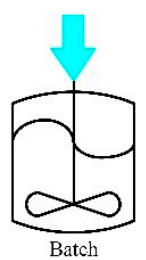

Hydrogen-ondemand system combined of PBR and batch reactor

Figure 7. An instantaneous hydrogen generation rate obtained by the combination of impulse function (batch reactor) and pulse function (PBR) of the $\mathrm{NaBH}_{4}$ feed flowrate.

\subsection{Feeding Method}

To obtain an instantaneous hydrogen generation rate, the hydrogen generation rate can be expressed as a step function:

$$
F_{H_{2}}(s)=\frac{\Delta F_{H_{2}}}{s}
$$

where $\Delta F_{H 2}$ is the derivation of the desired hydrogen generation rate.

Substituting Equation (18) into Equation (17), the $\mathrm{NaBH}_{4}$ feed flowrate can be retrogressively calculated as follows:

$$
F_{\mathrm{NaBH}_{4}, \mathrm{O}}(s)=\frac{\Delta F_{\mathrm{H}_{2} \tau}}{K}+\frac{\Delta F_{\mathrm{H}_{2}}}{K s}
$$

The inverse Laplace Transform of Equation (19), the $\mathrm{NaBH}_{4}$ feed flowrate can be derived analytically, which can be expressed as the combination of the impulse and step functions:

$$
F_{\mathrm{NaBH}_{4}, 0}(t)=\left[\frac{\Delta F_{\mathrm{H}_{2}} \tau}{K}\right] \cdot \delta(t)+\frac{\Delta F_{\mathrm{H}_{2}}}{K} \cdot u(t)
$$

where $\delta(t)$ is the impulse function and $u(t)$ is the unit step function.

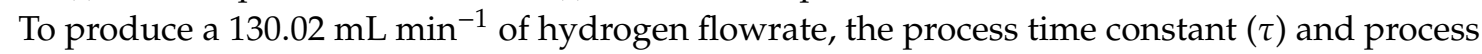
gain $(K)$ of Equation (17) are $1.67 \mathrm{~min}$ and 4 at $70^{\circ} \mathrm{C}$. A combination of the impulse and step functions of the feed flowrate (shown in Figure 7) can achieve an instantaneous and constant hydrogen generation rate. The step response of hydrogen generation rates relates to a PBR design, and the impulse response of hydrogen generation rate relates to a batch reactor design where the initial volume of the $\mathrm{NaBH}_{4}$ is $7.95 \times 10^{-8} \mathrm{~m}^{3}\left(=0.00538 \times(1.67 / 4)=0.00225 \mathrm{~mol}=0.0795 \mathrm{~mL}\right.$ of $\left.\mathrm{NaBH}_{4}\right)$. It's a concept of a design procedure suitable for hydrogen-on-demand systems.

\subsection{Implementation}

In Figure 7, a given amount of $7.95 \times 10^{-8} \mathrm{~m}^{3}$ of the $\mathrm{NaBH}_{4}$ feed is initially placed in the reaction chamber (the area of the impulse function shown in Figure 7). The reaction is started by adding the 
constant $\mathrm{NaBH}_{4}$ feed flowrate (the area of the function shown in Figure 7). An instantaneous hydrogen generation rate can then be obtained.

However, in real applications, it's impossible to supply a $7.95 \times 10^{-8} \mathrm{~m}^{3}$ amount of the $\mathrm{NaBH}_{4}$ feed immediately (impulse function) when the sodium borohydride hydrolysis reactors are restarted. In order to solve this problem, for a subsequent start-up, the pulse function of $\mathrm{NaBH}_{4}$ feed flowrate is used instead of the impulse function. The pulse function of input $\mathrm{NaBH}_{4}$ feed flowrate can be expressed as:

$$
F_{\mathrm{NaBH} 4,0}(t)=\left\{\begin{array}{lc}
0 ; & t<0 \\
\Delta F_{\mathrm{NaBH} 4,0} ; & 0<t<t_{S} \\
0 ; & t>t_{S}
\end{array}\right.
$$

where $\Delta F_{\mathrm{NaBH} 4,0}$ is the magnitude of the pulse function and $t_{S}$ is the start-up time.

Taking a Laplace Transform of Equation (21), and substituting the $\mathrm{NaBH}_{4}$ feed flowrate into Equation (17). Then, taking inverse Laplace Transform, the hydrogen generation rate with respect to time is given as:

$$
F_{H 2}(t)= \begin{cases}K \Delta F_{N a B H 4,0}\left[\left(1-e^{-t / \tau}\right)\right] ; & t<t_{S} \\ K \Delta F_{N a B H 4,0}\left[\left(1-e^{-t / \tau}\right)-\left(1-e^{-\left(t-t_{S}\right) / \tau}\right)\right] ; & t>t_{S}\end{cases}
$$

For the condition of $t=t_{S}$, the hydrogen flowrate is equal to the desired hydrogen generation rate, which is $F_{H 2}(t)=\Delta F_{H 2}$. Therefore, the magnitude of the pulse function can be computed as:

$$
\Delta F_{N a B H 4,0}=\frac{\Delta F_{H 2}}{K\left(1-e^{-t_{S} / \tau}\right)}
$$

The total additional amount of $\mathrm{NaBH}_{4}$ feed stream $\left(F_{\mathrm{NaBH} 4,0}^{\mathrm{T}}\right)$ is $\Delta F_{\mathrm{NaBH} 4,0} \times t_{s}$.

Once the required start-up time is determined, the magnitude of the pulse function and the total additional amount of $\mathrm{NaBH}_{4}$ feed stream can be calculated. To produce a $130.02 \mathrm{~mL} \mathrm{~min}{ }^{-1}$ hydrogen flowrate, the process time constant $(\tau)$ and process gain $(K)$ of Equation $(17)$ are $100.4 \mathrm{~s}$ and 4 at $70{ }^{\circ} \mathrm{C}$. Pulse flowrate to normal $\mathrm{NaBH}_{4}$ feed flowrate ratios are 2, 4, 8 and 16, and the start-up times can be calculated by Equation (25) and are 69.59, 28.88, 13.41 and $6.48 \mathrm{~s}$, respectively. Figure 8 shows the simulation results with different high points of the pulse function. The higher value of the pulse function; the shorter the start-up time of the hydrogen generation rate.

Based on previous results, the turn down ratio of feed pump can be calculated. The turndown ratio (TR) between the maximum $\mathrm{NaBH}_{4}$ feed flowrate $\left(\Delta F_{\mathrm{NaBH}, 0}\right)$ and the nominal $\mathrm{NaBH}_{4}$ feed flowrate $\left(\Delta \bar{F}_{\mathrm{NaBH}, 0}\right)$ can be defined as:

$$
T R=\frac{\Delta F_{\mathrm{NaBH4}, 0}}{\Delta \bar{F}_{\mathrm{NaBH} 4,0}}=\frac{\Delta F_{H 2} /\left[K\left(1-e^{-t_{S} / \tau}\right)\right]}{\Delta F_{H 2} / K}=\frac{1}{\left(1-e^{-t_{S} / \tau}\right)}
$$

where $\Delta \bar{F}_{\mathrm{NaBH}, 0}$ is the nominal $\mathrm{NaBH}_{4}$ feed flowrate, which is the magnitude of the step function in Equation (17). Figure 9a shows that an increase in the start-up time causes a decrease in the turndown ratio. When the start-up time $\left(t_{S}\right)$ is determined in Equation (24), the value of TR can be calculated. To comply with a start-up time of $5 \mathrm{~s}$ (or $0.083 \mathrm{~min}$ ) (set by US Department of Energy fuel cell start-up time of less than $5 \mathrm{~s}$ to produce hydrogen), the turndown ratio is at about $20\left(\right.$ at $\left.t_{S} / \tau=0.083 \mathrm{~min} / 1.67 \mathrm{~min}=0.05\right)$. Figure $9 \mathrm{~b}$ shows that an increase in the start-up time causes an increase in total additional $\mathrm{NaBH}_{4}$. These results show the start-up time of hydrogen generation using $\mathrm{NaBH}_{4}$ hydrolysis reaction can be reduced by providing a combined higher pulse function/step function feed flowrate. 


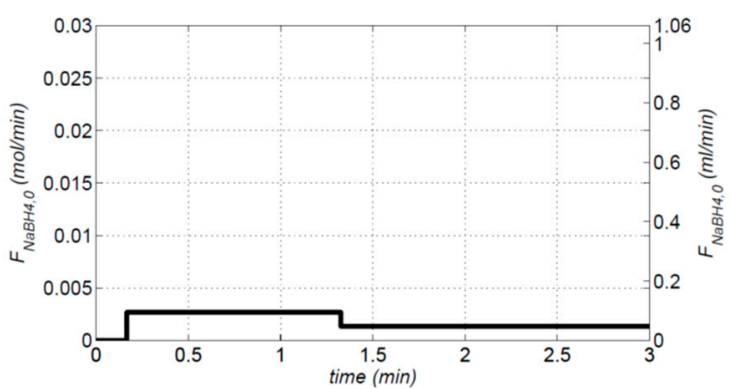

(a)

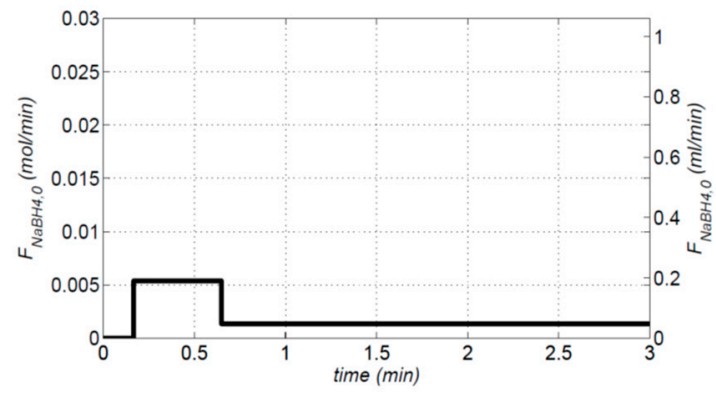

(c)

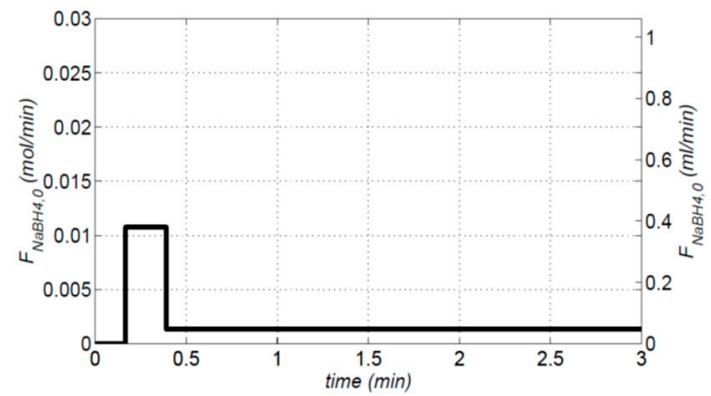

(e)

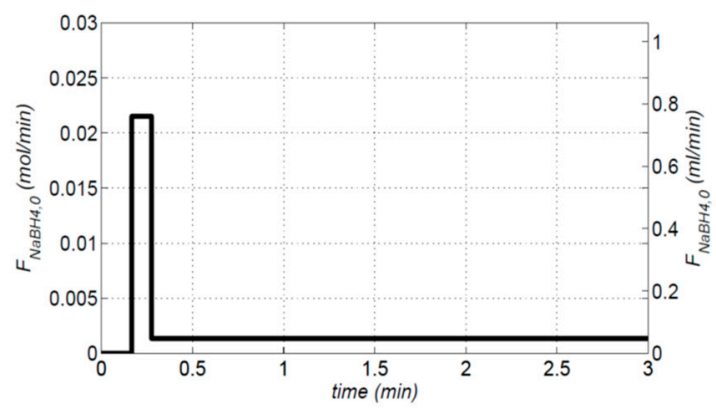

(g)

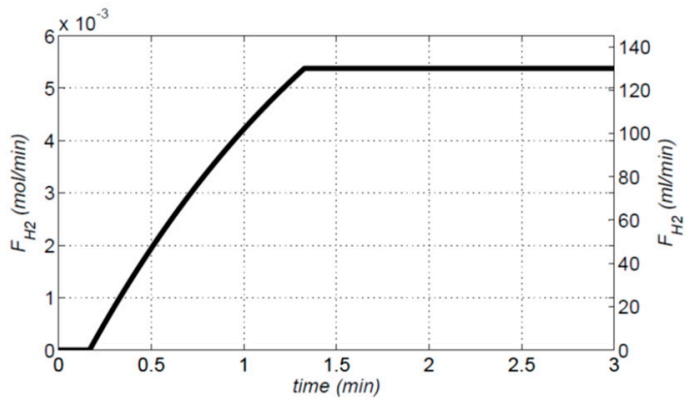

(b)

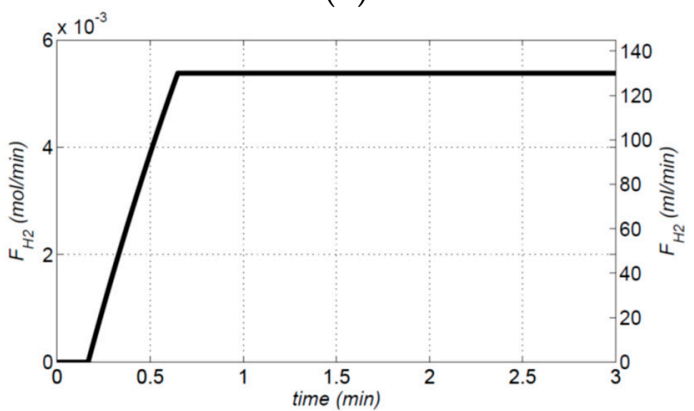

(d)

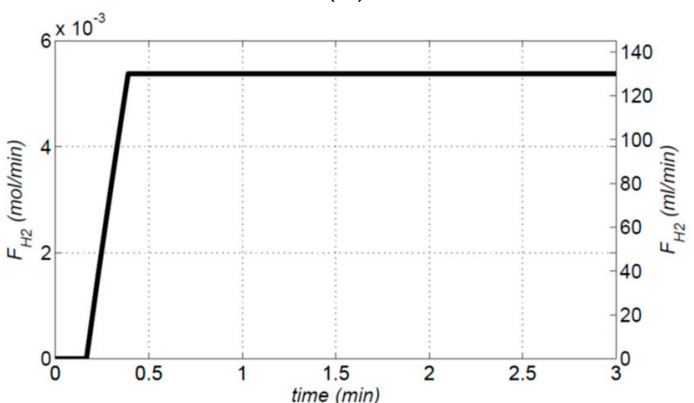

(f)

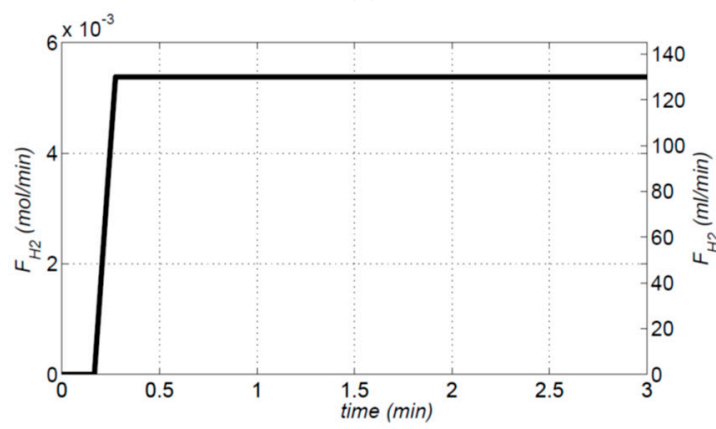

(h)

Figure 8. Feed flowrate and hydrogen generation flowrate of the hydrogen-on-demand system with a combined pulse and step function of feed $\mathrm{NaBH}_{4}$ flowrate and pulse flowrate to normal feed flowrate ratio at $2(\mathbf{a}, \mathbf{b}), 4(\mathbf{c}, \mathbf{d}), 8(\mathbf{e}, \mathbf{f}), 16(\mathbf{g}, \mathbf{h})$ with $\tau=1.67 \mathrm{~min}$. 


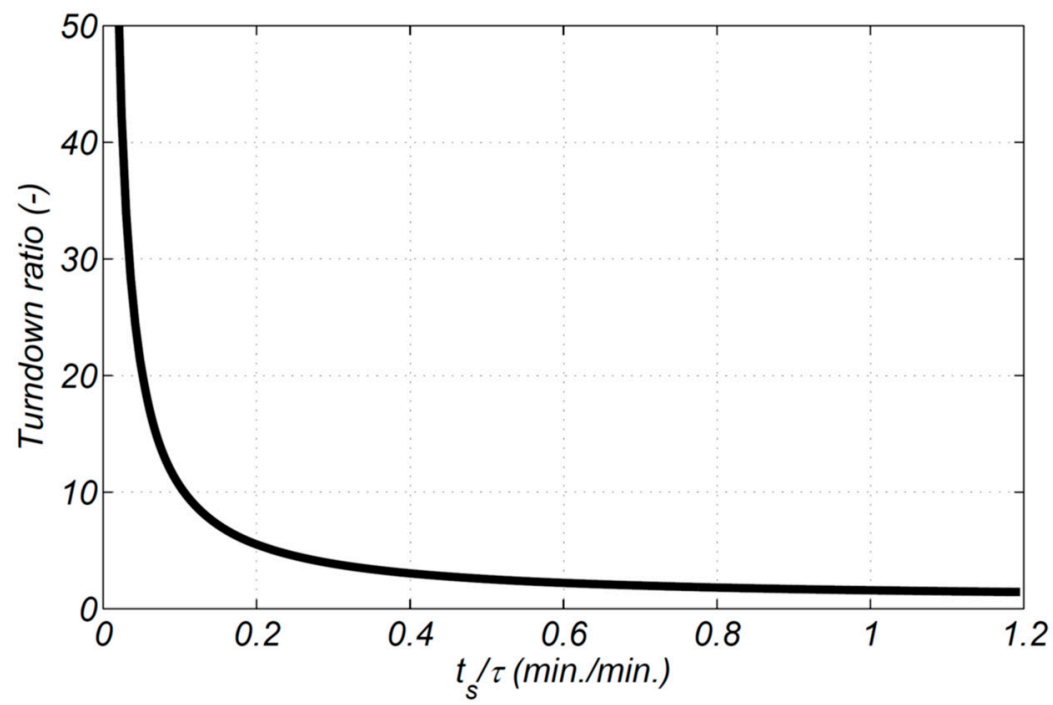

(a)

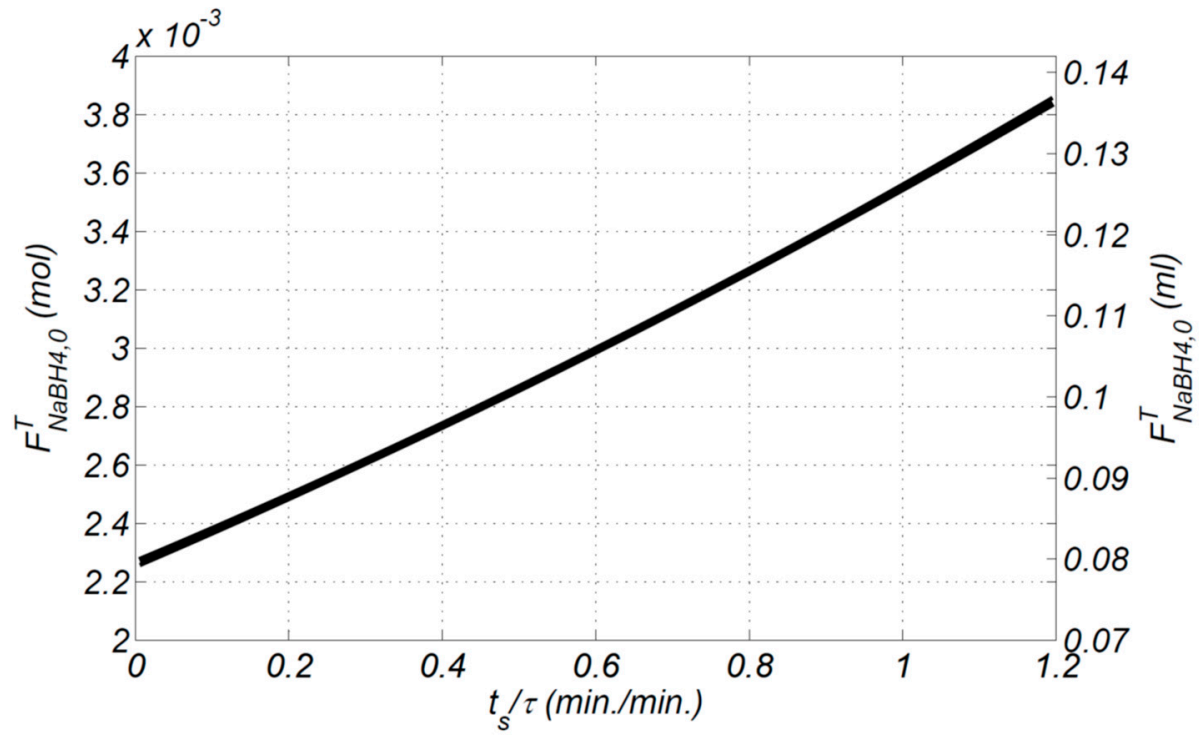

(b)

Figure 9. Start-up time versus (a) Turndown ratio, (b) $F_{\mathrm{NaBH} 4,0}^{T}(\mathrm{~mol}$ or $\mathrm{ml}$ ) at $\tau=1.67 \mathrm{~min}$.

\section{Experiment Validation}

The experiments of the sodium borohydride hydrolysis reaction for hydrogen generation were set-up and performed at the Tamkang University/Process System Engineering Laboratories facility in Taipei, Taiwan. Figure 1 shows the experimental setup of the sodium borohydride hydrolysis reaction for hydrogen generation. The $1.02 \mathrm{~mL} \mathrm{~min}^{-1}$ feed flowrate which included $5 \mathrm{wt} . \% \mathrm{NaBH}_{4}$ solution and $2 \mathrm{wt} . \% \mathrm{NaOH}$ solution as an alkaline stabilizer, was pumped into the reactor and came into contact with the $0.0175 \mathrm{~kg}$ Co-B/IR-120 catalyst. The hydrolysis reactor was placed in the water bath, and the temperature was set at $70{ }^{\circ} \mathrm{C}$. The hydrogen was generated in the reactor and exited from the top channel via a tube, then removed the water vapor by a steam trap. The hydrogen generation rate was recorded by the mass flowmeter. When the hydrogen flowrate stabilized at $130.0 \mathrm{~mL} \mathrm{~min}{ }^{-1}$ at around $1200 \mathrm{~s}$, the feed flowrate was shut-down which caused the hydrogen flowrate to decrease from $130.0 \mathrm{~mL} \mathrm{~min}^{-1}$ to zero. In order to simulate the start-up and shut-down situations of a $3 \mathrm{C}$ device, the feed flowrate was adjusted to the normal flowrate and then to zero. Once the computer start-up process is completed, then a regular hydrogen flow rate can be obtained to maintain the in-use power level. When the computer is shut down and restarted, the pulse function of feed flowrate is 
used instead of the impulse function. Typical power requirements for different activities are shown in Figure 10. Because of the limitation of the maximum flowrate $\left(2.4 \mathrm{~mL} \mathrm{~min}^{-1}\right)$ of the rotary pump, the normal (Step) and maximum (Pulse) flowrates are set at 1.02 and $2.04 \mathrm{~mL} \mathrm{~min}^{-1}$, respectively. The feed flowrate was restarted at $2250 \mathrm{~s}$ using a combined pulse/step function (The pulse height, period and step height are $2.04 \mathrm{~mL} \mathrm{~min}^{-1}, 70.0 \mathrm{~s}$ and $1.02 \mathrm{~mL} \mathrm{~min}^{-1}$ ). This resulted in a start-up time reduction from $392 \mathrm{~s}$. to $70 \mathrm{~s}$. The feed flowrate was turned to zero at $4250 \mathrm{~s}$. the shut-down time was around $392 \mathrm{~s}$. The second start-up and shut-down cycle was tested and the same result was obtained. The simulation result fits with our experiment data very well.

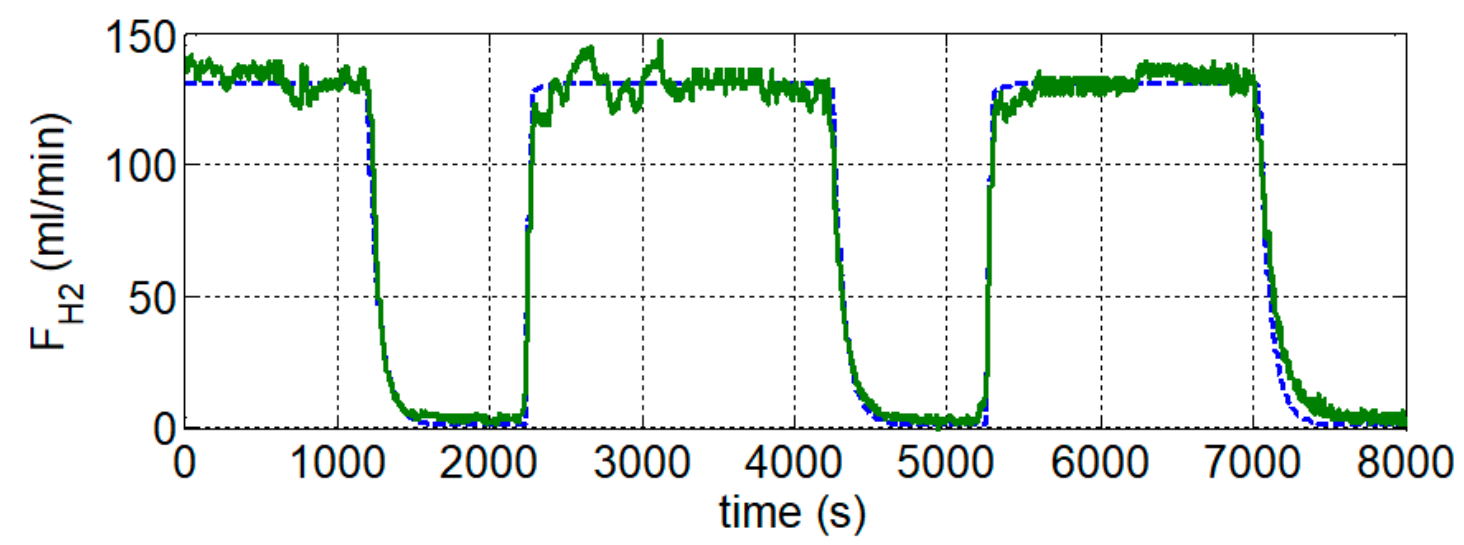

(a)

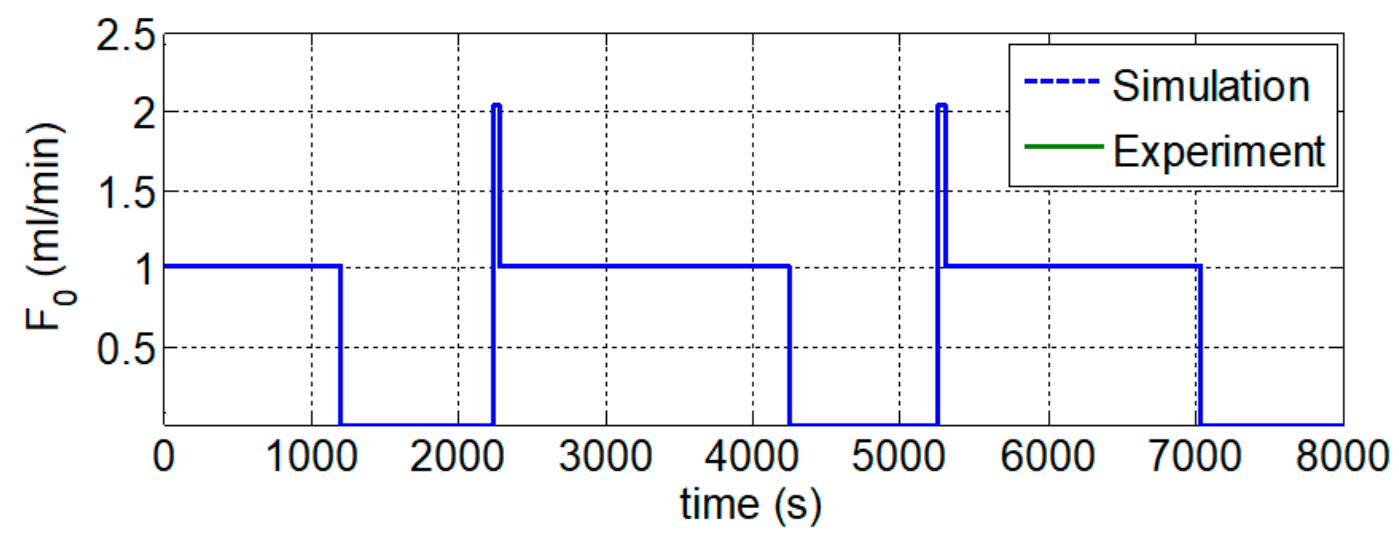

(b)

Figure 10. Typical power requirements for different activities, namely; computer in use, sleep mode and shut down (a) hydrogen generation flowrate, (b) feed flowrate.

\section{Conclusions}

In this work, the operational procedure for a hydrogen-on-demand system was proposed. A first-order transfer function between the input $\mathrm{NaBH}_{4}$ feed flowrate and the output hydrogen is analytically derived. The time constant of the transfer function is a function of the reciprocal of the product of the reaction rate constant and the catalyst weight into the liquid volume of the reactor. In the reactor design phase, increasing the catalyst performance and the operating temperature and decreasing the bulk density of the reactor $\left(W_{\text {cat }} / V_{L}\right)$ can shorten the dynamic response time of the hydrogen generation rate. However, there is an improved limitation of the dynamic response time of the hydrogen generation rate in the design phase. In the reactor operation phase, in order to achieve the on-demand hydrogen generation rate, the feed flowrate should be supplied using a combination of impulse function and step function of the $\mathrm{NaBH}_{4}$ feed flowrate. For different power requirements, the pulse/step function of the $\mathrm{NaBH}_{4}$ feed flowrate is used for a subsequent start-up. 
Hence, a systematic feeding procedure can then be constructed for shortening start-up times. In order to achieve the DOE's fuel cell $5 \mathrm{~s}$ start-up time goal, the turn down ratio of the feed flowrate should be increased to 20 to satisfy the hydrogen generation rate requirement. Finally, the experiment was set-up to validate the theoretical derivation result.

Author Contributions: Proposed the concept, Y.-H.C.; developed the methodology for experimental work and analysis, Y.-H.C. and J.-C.L.; conducted the simulation and data analysis, Y.-H.C. and J.-C.L. All authors contributed to the results, discussion, and conclusions. Y.-H.C. prepared the manuscript. All authors have read and agreed to the published version of the manuscript.

Funding: This research was funded by the Ministry of Science and Technology of Taiwan, grant number MOST 108-2221-E-032-028.

Conflicts of Interest: The authors declare no conflict of interest.

\section{Appendix A}

Assuming all the $\mathrm{NaBH}_{4}$ is exhausted in the effluent of the reactor (when $F_{\mathrm{NaBH}, n}$ equals to zero), the liquid volume $\left(V_{L}\right)$ and catalyst weight $\left(W_{\text {cat }}\right)$ in each lump of the reactor stay constant. Equation (6) can be simplified and rewritten as:

$$
\begin{aligned}
& \frac{V_{L}}{n} \frac{d\left(C_{\mathrm{NaBH}}, 1\right)}{d t}=F_{\mathrm{NaBH} 4,0}-F_{\mathrm{NaBH} 4,1}-k C_{\mathrm{NaBH} 4,1} \frac{W_{\text {cat }}}{n} \\
& \frac{V_{L}}{n} \frac{d\left(C_{\mathrm{NaBH}, 2}\right)}{d t}=F_{\mathrm{NaBH} 4,0}-F_{\mathrm{NaBH} 4,1}-k C_{\mathrm{NaBH} 4,2} \frac{W_{\text {cat }}}{n} \\
& \begin{array}{cccc}
\vdots & \vdots & \vdots & \vdots \\
\frac{V_{L}}{n} \frac{d\left(C_{N a B H 4, i}\right)}{d t}= & F_{N a B H 4, i-1} & -F_{N a B H 4, i} & k C_{N a B H 4, i} \frac{W_{c a t}}{n}
\end{array} \\
& \begin{array}{cccc}
\vdots & \vdots & \vdots & \vdots
\end{array} \\
& \frac{V_{L}}{n} \frac{d\left(C_{N a B H 4, n}\right)}{d t}=F_{N a B H 4, n-1}-k C_{N a B H 4, n} \frac{W_{c a t}}{n}
\end{aligned}
$$

where $n$ is the total number of lumps.

The hydrogen flowrate can be defined as follows:

$$
\begin{array}{cc}
F_{H 2,1} & =4 k C_{\mathrm{NaBH} 4,1} \frac{W_{\text {cat }}}{n} \\
F_{H 2,2} & =4 k C_{\mathrm{NaBH}, 2,2} \frac{W_{\text {cat }}}{n} \\
\vdots & \vdots \\
F_{H 2, i} & =4 k C_{\mathrm{NaBH}, i} \frac{W_{\text {cat }}}{n} \\
\vdots & \vdots \\
F_{H 2, n} & =4 k C_{\mathrm{NaBH} 4, n} \frac{W_{\text {cat }}}{n}
\end{array}
$$

Substituting Equation (A2) into Equation (A1) we have:

$$
\begin{gathered}
\frac{V_{L}}{4 k W_{c a t}} \frac{d F_{H 2,1}}{d t}=F_{N a B H 4,0}-F_{N a B H 4,1}-\frac{F_{H 2,1}}{4} \\
\frac{V_{L}}{4 k W_{c a t}} \frac{d F_{H 2,2}}{d t}=F_{N a B H 4,1}-F_{N a B H 4,2}-\frac{F_{H 2,2}}{4} \\
\vdots \quad \vdots \quad \vdots \quad \vdots \\
\frac{V_{L}}{4 k W_{c a t}} \frac{d F_{H 2, i}}{d t}=F_{N a B H 4, i-1}-F_{N a B H 4, i}-\frac{F_{H 2, i}}{4} \\
\vdots \\
\frac{V_{L}}{4 k W_{c a t}} \frac{d F_{H 2, n}}{d t}=F_{N a B H 4, n-1}-\frac{F_{H 2, n}}{4}
\end{gathered}
$$


Taking a Laplace Transform of Equation (A3), the relationship between the feed $\mathrm{NaBH}_{4}$ flowrate and the output hydrogen generation can be derived analytically:

$$
\begin{gathered}
F_{H 2,1}(s)=\frac{4}{\frac{V_{L}}{k W_{c a t}} s+1} F_{N a B H 4,0}(s)-\frac{4}{\frac{V_{L}}{k W_{c a t}} s+1} F_{N a B H 4,1}(s) \\
F_{H 2,2}(s)=\frac{4}{\frac{V_{L}}{k W_{c a t}} s+1} F_{N a B H 4,1}(s)-\frac{4}{\frac{V_{L}}{k W_{c a t}} s+1} F_{N a B H 4,2}(s) \\
\vdots \\
F_{H 2, i}(s)=\frac{4}{\frac{V_{L}}{k W_{c a t}} s+1} F_{N a B H 4, i-1}(s)-\frac{4}{\frac{V_{L}}{k W_{c a t}} s+1} F_{N a B H 4, i}(s) \\
\vdots \\
F_{H 2, n}(s)=\frac{4}{\frac{V_{L}}{k W_{c a t}} s+1} F_{N a B H 4, n-1}(s)
\end{gathered}
$$

The total hydrogen generation rate from each lump of the hydrolysis reactor is shown as follows:

$$
F_{H 2}(s)=F_{H 2,1}(s)+F_{H 2,2}(s)+\cdots+F_{H 2, n}(s)
$$

Summarizing each row of Equation (A4) and using definition of total hydrogen generation rate (Equation (A5)) gives:

$$
\begin{aligned}
F_{H 2}(s) & =F_{H 2,1}(s)+F_{H 2,2}(s)+\cdots+F_{H 2, n}(s) \\
& =\frac{4}{\left(V_{L} / k W_{c a t} s+1\right)} F_{N a B H 4,0}(s)
\end{aligned}
$$

\section{References}

1. Liu, B.H.; Li, Z.P. A review: Hydrogen generation from borohydride hydrolysis reaction. J. Power Sources 2009, 187, 527-534. [CrossRef]

2. Demirci, U.B.; Akdim, O.; Miele, P. Ten-year efforts and a no-go recommendation for sodium borohydride for on-board automotive hydrogen storage. Int. J. Hydrogen Energy 2009, 34, 2638-2645. [CrossRef]

3. Xia, Z.T.; Chan, S.H. Feasibility study of hydrogen generation from sodium borohydride solution for micro fuel cell applications. J. Power Sources 2005, 152, 46-49. [CrossRef]

4. Kim, J.H.; Lee, J.Y.; Choi, K.H.; Chang, H. Development of planar, air-breathing, proton exchange membrane fuel cell systems using stabilized sodium borohydride solution. J. Power. Sources 2008, 185, 881-885. [CrossRef]

5. Hsueh, C.L.; Liu, C.H.; Chen, B.H.; Lee, M.S.; Chen, C.Y.; Lu, Y.W.; Tsau, F.; Ku, J.R. A novel design of solid-state NaBH4 composite as a hydrogen source for 2W PEMFC applications. J. Power Sources 2011, 196, 3530-3538. [CrossRef]

6. Akdim, O.; Demirci, U.B.; Miele, P. Acetic acid, a relatively green single-use catalyst for hydrogen generation from sodium borohydride for hydrogen generation from sodium borohydride. Int. J. Hydrogen Energy 2009, 34, 7231-7238. [CrossRef]

7. Liu, B.H.; Li, Z.P.; Suda, S. Nickel- and cobalt-based catalysts for hydrogen generation by hydrolysis of borohydride. J. Alloys Compd. 2006, 415, 288-293. [CrossRef]

8. Metin, O.; Ozkar, S. Hydrogen generation from the hydrolysis of sodium borohydride by using water dispersible, hydrogen phosphate-stabilized nickel (0) nanoclusters as catalyst. Int. J. Hydrogen Energy 2007, 32, 1707-1715. [CrossRef]

9. Ye, W.; Zhang, H.M.; Xu, D.Y.; Ma, L.; Yi, B.L. Hydrogen generation utilizing alkaline sodium borohydride solution and supported cobalt catalyst. J. Power Sources 2007, 164, 544-548. [CrossRef]

10. Malvadkar, N.; Park, S.; Urquidi-MacDonald, M.; Wang, H.; Demirel, M.C. Catalytic activity of cobalt deposited on nanostructured poly (p-xylene) films. J. Power Sources 2008, 182, 323-328. [CrossRef]

11. Jeong, S.U.; Kim, R.K.; Cho, E.A.; Kim, H.J.; Nam, S.W.; Oh, I.H.; Hong, S.A.; Kim, S.H. A study on hydrogen generation from $\mathrm{NaBH} 4$ solution using the high-performance Co-B catalyst. J. Power Sources 2005, 144 129-134. [CrossRef]

12. Zhao, J.Z.; Ma, H.; Chen, J. Improved hydrogen generation from alkaline NaBH4 solution using carbon-supported Co-B as catalysts. Int. J. Hydrogen Energy 2007, 18, 4711-4716. [CrossRef] 
13. Hua, D.; Hanxi, Y.; Xinping, A.; Chuansin, C. Hydrogen production from catalytic hydrolysis of sodium borohydride solution using nickel boride catalyst. Int. J. Hydrogen Energy 2003, 28, 1095-1100. [CrossRef]

14. Ingersoll, J.C.; Mani, N.; Thenmozhiyal, J.C.; Muthaiah, A. Catalytic hydrolysis of sodium borohydride by a novel nickel-cobalt-boride catalyst. J. Power Sources 2007, 173, 450-457. [CrossRef]

15. Hung, A.J.; Tsai, S.F.; Hsu, Y.Y.; Ku, J.R.; Chen, Y.H.; Yu, C.C. Kinetics of sodium borohydride hydrolysis reaction for hydrogen generation. Int. J. Hydrogen Energy. 2008, 33, 6205-6215. [CrossRef]

16. Pena-Alonso, R.; Sicurelli, A.; Callone, E.; Carturan, G.; Raj, R. A picoscale catalyst for hydrogen generation from NaBH4 for fuel cells. J. Power Sources 2007, 165, 315-323. [CrossRef]

17. Zhang, J.S.; Delgass, W.N.; Fisher, T.S.; Gore, J.P. Kinetics of Ru-catalyzed sodium borohydride hydrolysis. J. Power Sources 2007, 164, 772-781. [CrossRef]

18. Andrieux, J.; Demirci, U.B.; Miele, P. Langmuir-Hinshelwood kinetic model to capture the cobalt nanoparticles-catalyzed hydrolysis of sodium borohydride over a wide temperature range. Catal. Today 2011, 170, 13-19. [CrossRef]

19. Liu, C.H.; Chen, B.H.; Hsueh, C.L.; Ku, J.R.; Tsau, F.H.; Hwang, K.J. Preparation of magnetic cobalt-based catalyst for hydrogen generation from alkaline NaBH4 solution. Appl. Catal. B 2009, 91, 368-379. [CrossRef]

20. Chen, Y.H.; Pan, C.Y. Effect of various Co-B catalyst synthesis conditions on catalyst surface morphology and NaBH4 hydrolysis reaction kinetic parameters. Int. J. Hydrogen Energy 2014, 39, 1648-1663. [CrossRef]

21. Prosini, P.P.; Gislon, P. A hydrogen refill for cellular phone. J. Power Sources 2006, 161, 290-293. [CrossRef]

22. Pozio, A.; De Francesco, M.; Monteleone, G.; Oronzio, R.; Galli, S.; D’Angelo, C.; Marrucci, M. Apparatus for the production of hydrogen from sodium borohydride in alkaline solution. Int. J. Hydrogen Energy 2008, 33, 51-56. [CrossRef]

23. Gislon, P.; Monteleone, G.; Prosini, P.P. Hydrogen production from solid sodium borohydride. Int. J. Hydrogen Energy 2009, 34, 929-937. [CrossRef]

24. Oronzio, R.; Monteleone, G.; Pozio, A.; De Francesco, M.; Galli, S. New reactor design for catalytic sodium borohydride hydrolysis. Int. J. Hydrogen Energy 2009, 34, 4555-4560. [CrossRef]

25. Prosini, P.P.; Gislon, P. Water consumption during solid state sodium borohydride hydrolysis. Int. J. Hydrogen Energy 2010, 35, 12234-12238. [CrossRef]

26. Galli, S.; De Francesco, M.; Monteleone, G.; Oronzio, R.; Pozio, A. Development of a compact hydrogen generator from sodium borohydride. Int. J. Hydrogen Energy 2010, 35, 7344-7349. [CrossRef]

27. Richardson, B.S.; Birdwell, J.F.; Pin, F.G.; Jansen, J.F.; Lind, R.F. Sodium borohydride based hybrid power system. J. Power Sources 2005, 145, 21-29. [CrossRef]

28. Zhang, J.; Zheng, Y.; Gore, J.P.; Mudawar, I.; Fisher, T.S. 1 kWe sodium borohydride hydrogen generation system Part II: Reactor modeling. J. Power Sources 2007, 170, 150-159. [CrossRef]

29. Krishnan, P.; Advani, S.G.; Prasad, A.J. Thin-film CoB catalyst templates for the hydrolysis of NaBH4 solution for hydrogen generation. Appl. Catal. B Environ. 2009, 86, 137-144. [CrossRef]

30. Luyben, M.L.; Luyben, W.L. Essentials of Process Control; McGRAW-Hill: New York, NY, USA, 1997.

(C) 2020 by the authors. Licensee MDPI, Basel, Switzerland. This article is an open access article distributed under the terms and conditions of the Creative Commons Attribution (CC BY) license (http://creativecommons.org/licenses/by/4.0/). 